\title{
Mitochondria Distinguish Granule-Stored from de novo Synthesized Tumor Necrosis Factor Secretion in Human Mast Cells
}

\author{
Bodi Zhang a, b, d Zuyi Weng ${ }^{\text {a,d }} \quad$ Nikolaos Sismanopoulos ${ }^{a, g}$ Sharhzad Asadia, d, e \\ Anastasia Therianou $^{\mathrm{h}}$ Konstantinos-Dionysios Alysandratos ${ }^{\mathrm{a}, \mathrm{g}}$ \\ Asimenia Angelidou ${ }^{a, g}$ Orian Shirihai ${ }^{f, h}$ Theoharis C. Theoharides ${ }^{a-d, g}$ \\ ${ }^{a}$ Molecular Immunopharmacology and Drug Discovery Laboratory, Department of Molecular Physiology and \\ Pharmacology, ${ }^{\mathrm{b}}$ Department of Biochemistry, Tufts University School of Medicine, ${ }^{\mathrm{c}}$ Department of Internal

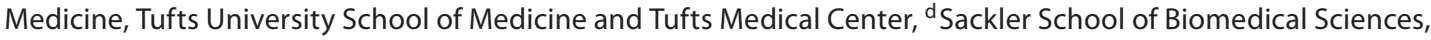 \\ Tufts University, ${ }^{e}$ Department of Pharmacy, Tufts Medical Center, and ${ }^{\mathrm{f}}$ Department of Medicine, Boston University \\ School of Medicine, Boston, Mass., USA; ${ }^{9}$ Allergy Clinical Research Center, Allergy Unit, Attikon General Hospital, \\ Athens University Medical School, and h First Department of Dermatology, A. Sygros Hospital, Athens Medical \\ School, Athens, Greece
}

\section{Key Words}

Lipopolysaccharide $\cdot$ Mast cells $\cdot$ Mitochondria $\cdot$ Substance $\mathrm{P} \cdot$ Tumor necrosis factor

\begin{abstract}
Background: Mast cells are immune cells derived from hematopoietic precursors that mature in the tissue microenvironment. Mast cells are critical for allergic, immune and inflammatory processes, many of which involve tumor necrosis factor (TNF). These cells uniquely store TNF in their secretory granules. Upon stimulation, mast cells rapidly (30 min) secrete $\beta$-hexosaminidase and granule-stored TNF through degranulation, but also increase TNF mRNA and release de novo synthesized TNF $24 \mathrm{~h}$ later. The regulation of these two distinct pathways is poorly understood. Methods: Human LAD2 leukemic mast cells are stimulated by substance $P$. TNF secretion and gene expression were measured by ELISA and real-time PCR, and mitochondrial dynamics was observed in live cells under confocal microscopy. Cell energy consumption was measured in terms of oxygen con-
\end{abstract}

sumption rate. Results: Here, we show that granule-stored TNF is preformed, and its secretion from LAD2 mast cells stimulated by substance $P(1)$ exhibits higher energy consumption and is inhibited by the mitochondrial ATP pump blocker oligomycin, (2) shows rapid increase in intracellular calcium levels, and (3) exhibits reversible mitochondrial translocation, from a perinuclear distribution to the cell surface, as compared to de novo synthesized TNF release induced by lipopolysaccharide. This mitochondrial translocation is confirmed using primary human umbilical cord bloodderived mast cells stimulated by an allergic trigger (lgE/ streptavidin). Conclusion: Our findings indicate that unique mitochondrial functions distinguish granule-stored from newly synthesized TNF release from human mast cells, thus permitting the versatile involvement of mast cells in different biological processes.

Copyright $\odot 2012$ S. Karger AG, Basel

\section{KARGER}

Fax +4161306 1234

E-Mail karger@karger.ch

www.karger.com (c) 2012 S. Karger AG, Basel

$1018-2438 / 12 / 1591-0023 \$ 38.00 / 0$

Accessible online at:

www.karger.com/iaa
Correspondence to: Prof. Dr. T.C. Theoharides

Department of Molecular Physiology and Pharmacology

Tufts University School of Medicine

136 Harrison Avenue, Boston, MA 02111 (USA)

Tel. +1 617636 6866, E-Mail theoharis.theoharides@tufts.edu 


\section{Introduction}

Mast cells are bone marrow-derived immune cells that can secrete prestored mediators such as histamine and tryptase through rapid (5-30 $\mathrm{min}$ ) degranulation as well as delayed (12-24 h) newly synthesized cytokines including interleukin-4 (IL-4) IL-6, IL-8, IL-13 and tumor necrosis factor (TNF) in response to allergic or neuropeptide triggers $[1,2]$. In fact, mast cells uniquely store TNF in secretory granules $[3,4]$. Stimulation of LAD2 [5] cells by substance $\mathrm{P}(\mathrm{SP})$ induces degranulation and secretion of prestored TNF [6], while stimulation with lipopolysaccharide (LPS) induces selective de novo synthesis and release of TNF without degranulation [7-9].

Other secretory cell types, like eosinophils, use distinct mechanisms for secretion, such as exocytosis of large storage granules and release from small secretory vesicles [10]. Mast cells can also release mediators selectively without degranulation [11], first reported for the release of serotonin without histamine [12] and later for IL-6 without histamine [13]. In both cases, this involved release from small vesicles ( $80 \mathrm{~nm}$ diameter) rather than from the typical secretory granules $(1,000 \mathrm{~nm}$ diameter) $[13,14]$. This ability, i.e. mast cell stimulation by allergic and non-immune triggers [15], as well as the synergistic stimulation by cytokines and neuropeptides [16] may allow mast cells to participate in a variety of distinct pathophysiological settings, in addition to allergy [17]. These include innate and acquired immunity [18], inflammation [11], autoimmunity [19], wound healing [20] and cancer growth [21], as well as atherosclerosis and obesity [22]. However, little is known about what distinguishes rapid degranulation from delayed selective cytokine release.

Degranulation from rat peritoneal mast cells requires metabolic energy and calcium [23]. Mitochondria are the primary source of energy production in eukaryotic cells and also have the ability to buffer calcium locally [24]. Moreover, mitochondria are dynamic organelles that participate in many complicated cell functions through morphological and localization changes [25]. Increasing evidence indicates the importance of mitochondrial dynamics in immune cell regulation. For instance, local ATP production by mitochondria is required for T-cell chemotaxis [26]. Moreover, mitochondrial translocation is required for T-cell 'immune synapse' formation and sustainable calcium influx [27]. On the other hand, local intracellular calcium changes can regulate mitochondrial dynamics and subcellular localization [28].
In this study, we show that SP-induced granule-stored TNF secretion, unlike newly synthesized selective TNF release, requires high mitochondrial energy consumption, intracellular calcium increase and mitochondrial translocation to the cell surface.

\section{Materials and Methods}

\section{Cell Lines and Reagents}

LAD2 culture cells [5] (from Dr. A.S. Kirshenbaum, NIH, Bethesda, Md., USA) were cultured in StemPro-34 medium (Invitrogen, Carlsbad, Calif., USA) supplemented with $100 \mathrm{ng} / \mathrm{ml} \mathrm{re-}$ combinant human stem cell factor (Swedish Orphan Biovitrum Sverige AB, Stockholm, Sweden) and $100 \mathrm{U} / \mathrm{ml}$ penicillin/streptomycin. Cells were grown in an incubator in $5 \% \mathrm{CO}_{2}$ at $37^{\circ} \mathrm{C}$. All cells were used during their logarithmic growth period. They were stimulated by either SP $(10 \mu \mathrm{M})$ or LPS $(10 \mathrm{ng} / \mathrm{ml})$ dissolved in distilled water.

Human cord blood-derived mast cells (hCBMCs) were grown from human cord blood obtained during normal deliveries in accordance with established institutional guidelines [29]. Briefly, mononuclear cells were isolated by layering heparin-treated cord blood onto lymphocyte separation medium (ICN Biomedical, Aurora, Ohio, USA). CD34+ progenitor cells were isolated from mononuclear cells by positive selection of AC133 (CD133+/ CD34+) cells by magnetic cell sorting (Miltenyi Biotech, Auburn, Calif., USA). hCBMCs were derived by the culture of CD34+ progenitor cells with minor modifications. For the first 6 weeks, CD34+ cells were cultured in AIM medium (Gibco, Grand Island, N.Y., USA) supplemented with $100 \mathrm{ng} / \mathrm{ml}$ recombinant human stem cell factor, and after 6 weeks, $50 \mathrm{ng} / \mathrm{ml} \mathrm{IL-6}$ (Chemicon, Billerica, Mass., USA) was added and cultured at $37^{\circ} \mathrm{C}$ in $5 \% \mathrm{CO}_{2}$ balanced air. Mast cell viability was determined by trypan blue $(0.3 \%)$ exclusion. Cells were stimulated first, passively sensitized with human monoclonal IgE $(1 \mu \mathrm{g} / \mathrm{ml}$; EMD Bioscience, Darmstadt, Germany) for $24 \mathrm{~h}$ and then with streptavidin $(125 \mathrm{ng} / \mathrm{ml}$; Sigma, St. Louis, Mo., USA ) for $30 \mathrm{~min}$ as indicated [30].

\section{TNF Secretion Assay}

LAD2 cells were treated with SP (10 $\mu \mathrm{M}$; Sigma), in order to achieve the strongest possible degranulation, or with LPS (10 ng/ $\mathrm{ml}$; Sigma) for $30 \mathrm{~min}, 6$ and $24 \mathrm{~h}$. TNF release was measured by ELISA (R\&D Systems, Minneapolis, Minn., USA) in the supernatant fluid. In certain experiments, LAD2 cells were pretreated with the transcription inhibitor actinomycin D (15 $\mu \mathrm{M}$ for $1 \mathrm{~h}$; Sigma) before stimulation with SP.

\section{Mast Cell Degranulation Assay}

$\beta$-Hexosaminidase ( $\beta$-hex) secretion, as an index of mast cell degranulation, was assayed using a fluorometric assay as previously reported. Briefly, $\beta$-hex activity in the supernatant fluid and cell lysates (LAD2 cells, $0.5 \times 10^{5} /$ tube, were lysed with $1 \%$ Triton $\mathrm{X}-100$ to measure residual cell-associated $\beta$-hex) were incubated with substrate solution ( $p$-nitrophenyl- $\mathrm{N}$-acetyl- $\beta$-D-glucosaminide; Sigma) in $0.1 \mathrm{M} \mathrm{NaOH} / 0.2 \mathrm{M}$ glycine. Absorbance was measured at $405 \mathrm{~nm}$ in an enzyme-linked immunosorbent assay reader, and the results are expressed as the percentage of $\beta$-hex released over the total. 
Fig. 1. Time course of SP and LPS-induced TNF secretion, mRNA expression and light microscopy of LAD2 cells. LAD2 cells were treated with SP $(10 \mu \mathrm{M})$ or LPS $(10 \mathrm{ng} / \mathrm{ml})$ for the time indicated. ${ }^{*} \mathrm{p}<$ $0.05 ;{ }^{* *} \mathrm{p}<0.01$. a TNF release was measured by ELISA (R\&D Systems) in the supernatant fluid $(\mathrm{n}=3)$. $\mathbf{b}$ TNF mRNA expression was measured by real-time PCR $(\mathrm{n}=3)$. c, $\mathbf{d}$ LAD2 cells were stained with toluidine blue and observed under light microscopy. LAD2 cells were treated with $\mathrm{SP}(10 \mu \mathrm{M})$ for $30 \mathrm{~min}(\mathbf{c})$ and $24 \mathrm{~h}(\mathbf{d})$. Scale bars $=5 \mu \mathrm{m}$. e $\beta$-hex release was measured $(\mathrm{n}=3)$. $\mathbf{f}$ TNF release was measured from cells treated with SP with or without actinomycin D (ActD) preincubation $(15 \mu \mathrm{g} /$ $\mathrm{ml}$ for $60 \mathrm{~min} ; \mathrm{n}=3$ ).

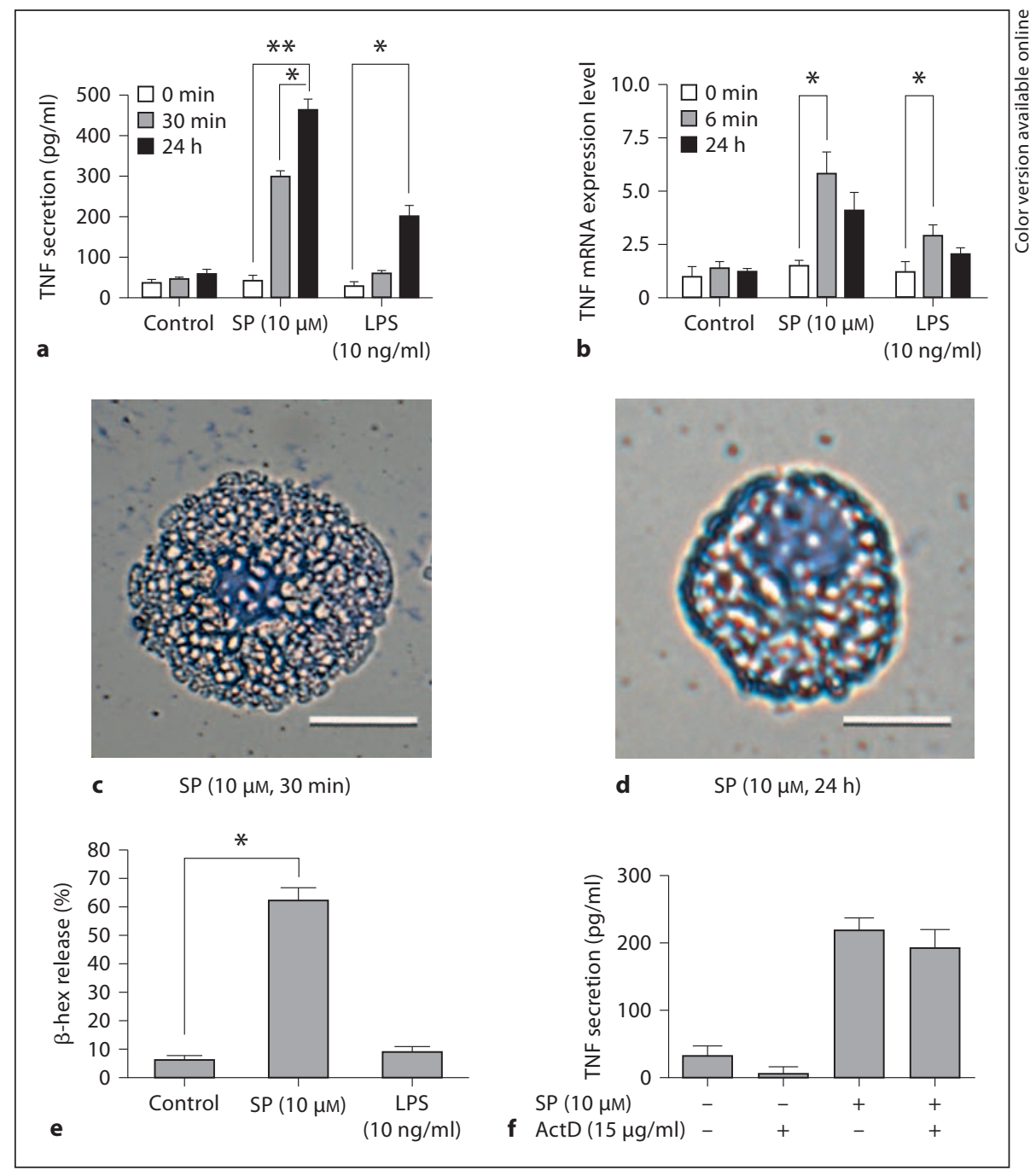

Quantitative Reverse Transcription PCR

Total RNA from cultured mast cells was isolated using Trizol reagent (Invitrogen) and RNeasy Mini Kit (Qiagen, Valencia, Calif., USA), respectively, according to the manufacturer's instructions. Reverse transcription was performed with $300 \mathrm{ng}$ of total RNA using the iScript cDNA synthesis kit (Bio-Rad, Hercules, Calif., USA). In order to measure TNF gene expression, quantitative real-time PCR was performed using Taqman gene expression assays. The following probes (Applied Biosystems, Carlsbad, Calif., USA) were used: TNF: Hs00542477_m1. Samples were run at 30 cycles using Applied Biosystems 7300 Real-Time PCR system (Applied Biosystems). Relative mRNA abundance was determined from standard curves run with each experiment, and TNF expressions were normalized to GAPDH (Hu, VIC TAMRA) as endogenous control.

\section{Intracellular Calcium Measurement}

LAD2 cells were loaded with $5 \mu \mathrm{M}$ Fura-2 AM (Invitrogen) for $20 \mathrm{~min}$, washed and incubated for another $20 \mathrm{~min}$ at $37^{\circ} \mathrm{C}$. Cells were then treated with either SP $(10 \mu \mathrm{M})$ or LPS $(10 \mathrm{ng} / \mathrm{ml})$. Fluo- rescence signals were acquired on Flexstation II (Bucher Biotech, Basel, Switzerland). Cytosolic calcium was calculated after subtraction of the background fluorescence by measuring the ratio of the two emission intensities (excitation at 340 and $380 \mathrm{~nm}$ ). Each experiment was repeated three times independently.

\section{Cell Energy Consumption Measurement}

LAD2 cell oxygen consumption rates were measured by Seahorse XF-24 Flux analyzer (Seahorse Bioscience Inc., North Billerica, Mass., USA). LAD2 cells were treated with SP $(10 \mu \mathrm{M})$ or LPS (10 ng/ml). Energy consumption was inhibited by the mitochondrial ATP pump blocker oligomycin. Cells were incubated with oligomycin ( $2 \mu \mathrm{M}$ for $20 \mathrm{~min}$; Sigma) and then treated with SP (10 $\mu \mathrm{M}$; Sigma) or LPS (10 ng/ml; Sigma). Experiments were conducted three times and results were similar.

\section{Confocal Microscopy}

Human mast cells were incubated with $20 \mathrm{nM}$ MitoTracker deep red probe (Invitrogen) for $20 \mathrm{~min}$ and $50 \mathrm{nM}$ LysoTracker DND (Invitrogen) for $30 \mathrm{~min}$. Cells were washed, moved to glass 


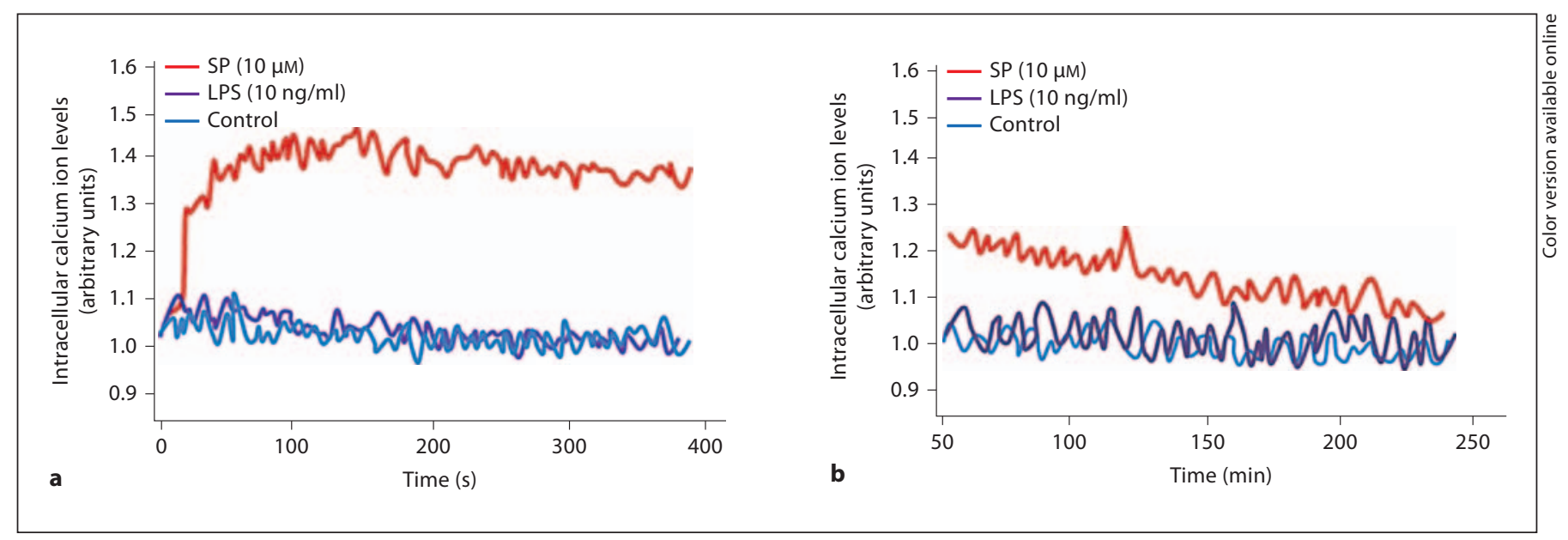

Fig. 2. Time course of SP and LPS stimulation on LAD2 mast cell cytosolic calcium changes. LAD2 cells were loaded with $5 \mu \mathrm{M}$ Fura-2 AM (Invitrogen) for $20 \mathrm{~min}$ at $37^{\circ} \mathrm{C}$, washed and incubated for another $20 \mathrm{~min}$. Cells were then treated with either SP $(10 \mu \mathrm{M})$ or LPS $(10 \mathrm{ng} / \mathrm{ml})$. Fluorescence signals were acquired on Flexstation II. The figure is representative of three repeats with similar results.

bottom culture dishes (MatTek, Ashland, Mass., USA) and observed using a Leica TCS SP2 confocal microscopy (Leica, Buffalo Grove, Ill., USA). Percentages of cells with mitochondrial translocation were counted from 100 randomly selected mast cells in each experiment by three independent operators. Confocal digital images were processed using the National Institute of Health ImageJ 1.32 and Adobe Photoshop 7.0 programs.

Data Analysis

Statistically significance differences between experimental samples and controls were determined by the Student t test using SigmaPlot 9.0 (SPSS, Chicago, Ill., USA). Differences were considered significant if $\mathrm{p}<0.05$.

\section{Results}

Time Course of SP and LPS-Induced TNF Secretion and Gene Expression

SP stimulation $(10 \mu \mathrm{M})$ results in secretion of granulestored TNF at $30 \mathrm{~min}$ (fig. 1a) as well as of de novo synthesized TNF $24 \mathrm{~h}$ later (fig. 1a). Stimulation with LPS (10 $\mathrm{ng} / \mathrm{ml}$ ) for $30 \mathrm{~min}$ has no effect on degranulation and granule-stored TNF (fig. 1a), but incubation for $24 \mathrm{~h}$ induces de novo synthesis and release of TNF without degranulation (fig. 1a). The gene expression level of TNF is significantly increased at 6 and 24 h both after SP and LPS stimulation (fig. 1b), indicating that SP and LPS induce de novo TNF synthesis. Under light microscopy, LAD2 cells stimulated by SP at 30 min show clear signs of degranulation (fig. 1c), but no signs of degranulation at
$24 \mathrm{~h}$ (fig. 1d). $\beta$-hex is also measured to confirm degranulation, and secretion occurred in parallel with preformed TNF (fig. 1e). In order to confirm that TNF secreted at $30 \mathrm{~min}$ is preformed, LAD2 cells are treated with RNA synthesis blocker actinomycin D $(15 \mu \mathrm{g} / \mathrm{ml}) 1 \mathrm{~h}$ before SP stimulation. There is no significant difference in TNF release amounts at $30 \mathrm{~min}$ with or without actinomycin D (15 $\mu \mathrm{g} / \mathrm{ml})$ (fig. 1f).

\section{Intracellular Calcium Levels of SP and LPS-Induced TNF Secretion}

SP $(10 \mu \mathrm{M})$ triggers a rapid significant cytosolic calcium increase within $1 \mathrm{~min}$ (fig. 2a). SP resulting in cytosolic calcium level returns to the same level of control after $50 \mathrm{~min}$. LPS $(10 \mathrm{ng} / \mathrm{ml})$ has no effect on intracellular level (fig. 2b).

\section{Energy Consumption during SP-Stimulated} Preformed and LPS-Induced de novo Synthesized TNF Release

To test if degranulation and de novo TNF secretion have different energy requirements, mitochondrial oxygen consumption was investigated during these two processes in LAD2 cells. SP induced a significant oxygen consumption spike, while there was almost no difference between LPS-stimulated and control cells (fig. 3a). In order to investigate if mitochondrial energy production is required for degranulation, mitochondrial energy production was blocked by pretreating LAD2 cells with the 


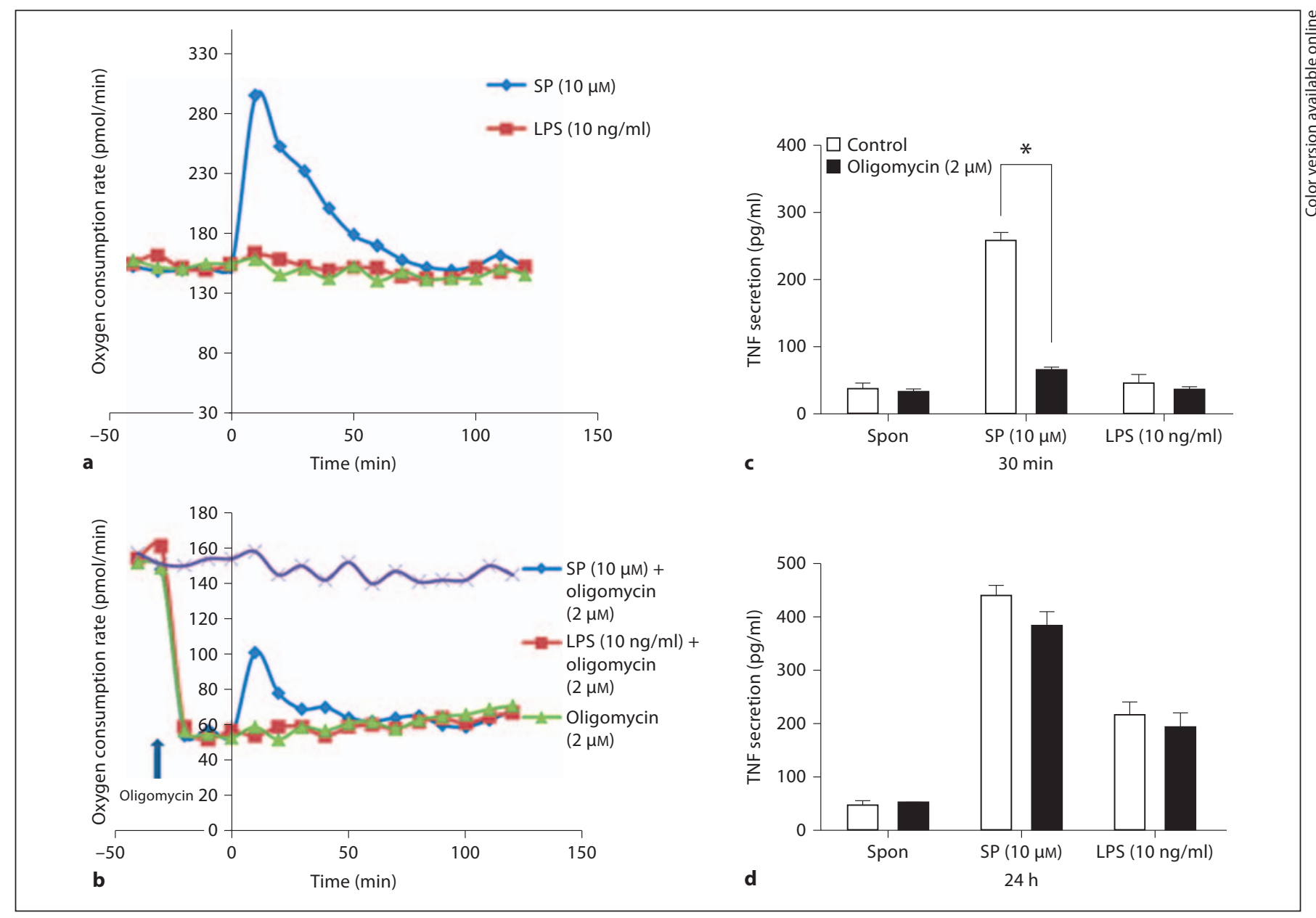

Fig. 3. Energy consumption in LAD2 cells stimulated by SP and LPS. a, b Cell oxygen consumption rates were measured by Seahorse XF-24 Flux analyzer (Seahorse Bioscience Inc.) in LAD2 cells treated with either SP $(10 \mu \mathrm{M})$ or LPS $(10 \mathrm{ng} / \mathrm{ml})$. LAD2 cells were pretreated (b) by the mitochondrial ATP pump blocker oli-

ATP synthase inhibitor oligomycin $(2 \mu \mathrm{M})$ for $30 \mathrm{~min}$. Oliygomycin treatment dropped the metabolic baseline of both SP- and LPS-treated cells to $30 \%$ of normal. In addition, the energy consumption spike (fig. 3b) was inhibited. Oliygomycin treatment also inhibits SP-simulated granule-stored TNF secretion at $30 \mathrm{~min}$ (fig. 3c). In contrast, there is no significant difference in SP-induced TNF release at $24 \mathrm{~h}$ with or without treatment with oligomycin (fig. 3d).

Degranulation, but Not de novo Cytokine Secretion, Results in Mitochondrial Translocation

Examination of resting live LAD2 cells by confocal microscopy shows that mitochondria stained with Mito- gomycin $(2 \mu \mathrm{M})$ for $20 \mathrm{~min}$ and were then treated with SP $(10 \mu \mathrm{M})$ or LPS $(10 \mathrm{ng} / \mathrm{ml})$ for $30 \mathrm{~min}$ or $24 \mathrm{~h}$, respectively. Experiments were conducted three times and one representative experiment is shown. TNF secretion was measured by ELISA as indicated before $(\mathrm{n}=3)$. Spon $=$ Spontaneous. ${ }^{*} \mathrm{p}<0.05$.
Tracker red are located around the nucleus as a 'mitochondrial pool' (indicated by the white dashed circle); very few mitochondria could be found close to the cell surface (fig. 4a). Since the average $\mathrm{pH}$ of mast cell granules is 5.5 [31], the lysosome dye LysoTracker [32] was used to stain secretory granules. After SP $(10 \mu \mathrm{M})$ stimulation for $30 \mathrm{~min}$ at $37^{\circ} \mathrm{C}$, mast cells undergo rapid degranulation as indicated by the content of numerous granules stained with LysoTracker outside the cell (fig. 4b, left panel). Following degranulation, many mitochondria appear to be smaller (fig. $4 \mathrm{~b}$, middle panel) and to have translocated close to the cell surface region (fig. 4b, right panel). This phenomenon is not observed in LPS-stimulated mast cells (fig. 4c). 


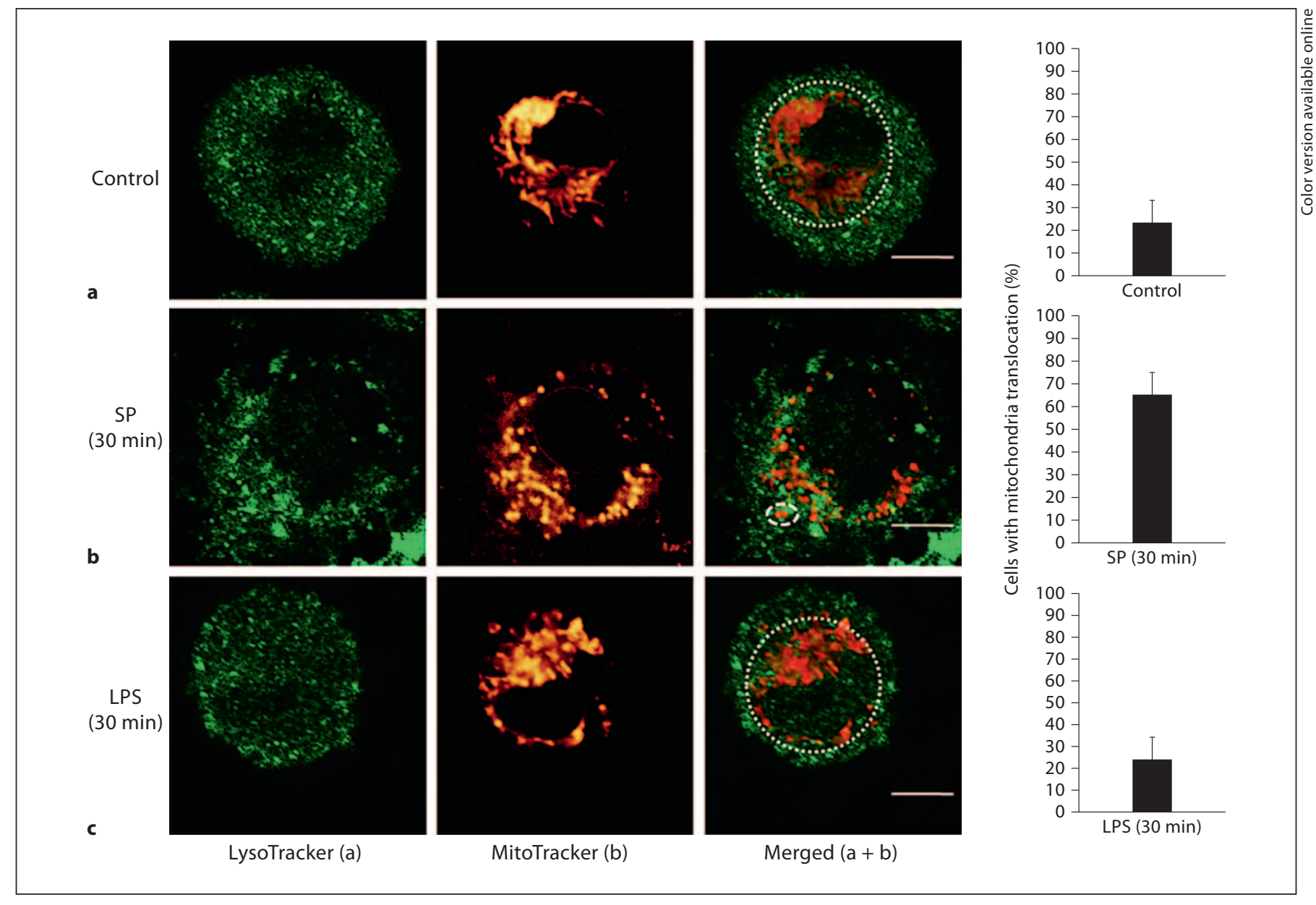

Fig. 4. Degranulation, but not de novo TNF release, is associated with mitochondrial translocation. LAD2 cells were stained with MitoTracker deep red probe $(20 \mathrm{nM})$ for $20 \mathrm{~min}$ and LysoTracker DND green probe (50 $\mathrm{nM}$ ) for $30 \mathrm{~min}$. The cells were harvested in glass bottom culture dishes and observed under the Leica TCS SP2 confocal microscope. The left panels depict granules in green and the middle panels represent mitochondrial fluorescence shown in red. The right panels represent images merged from the two previous panels. The white dashed circles outline the 'mitochondrial pool'. The graphs shown at the far right represent percentages of mast cells with mitochondrial translocation obtained from 100 randomly selected cells. a Control groups. b SP $(10 \mu \mathrm{M}$, $30 \mathrm{~min})$. c LPS (10 $\mathrm{ng} / \mathrm{ml}, 30 \mathrm{~min})$. Each experiment was repeated three times and was evaluated by three independent operators. Scale bars $=5 \mu \mathrm{m}$. The colors refer to the online version of the figure.

\section{Degranulation-Associated Mitochondrial Translocation Is Reversible}

Confocal images of SP-activated mast cells at $24 \mathrm{~h}$ show that there is no evidence of degranulation (fig. 5b). At $24 \mathrm{~h}$, it is obvious that most mitochondria were found again in the perinuclear region (fig. 5b). Only about $20 \%$ of cells contain translocated mitochondria, which is not different from that of controls. This finding indicates that degranulation-induced mitochondrial translocation is reversible. Just as there is no mitochondrial translocation 30 min after LPS stimulation (fig. 4c), there is no translocation at $24 \mathrm{~h}$ either; LPS-stimulated mast cells still con- tained intact mitochondria located in the perinuclear region (fig. 5c).

\section{IgE/Streptavidin-Stimulated hCBMCs Secrete \\ Preformed TNF, Associated with Mitochondrial \\ Translocation}

Under confocal microscopy, unstimulated hCBMCs (fig. 6a, upper panels), as well as those treated only with IgE $(1 \mu \mathrm{g} / \mathrm{ml})$ for $30 \mathrm{~min}$ (fig. 6a, middle panels), had most of their mitochondria interconnected in a 'net' located in the perinuclear region (within the dashed circles). In contrast, hCBMCs stimulated by $\operatorname{IgE}(1 \mu \mathrm{g} / \mathrm{ml})$ 


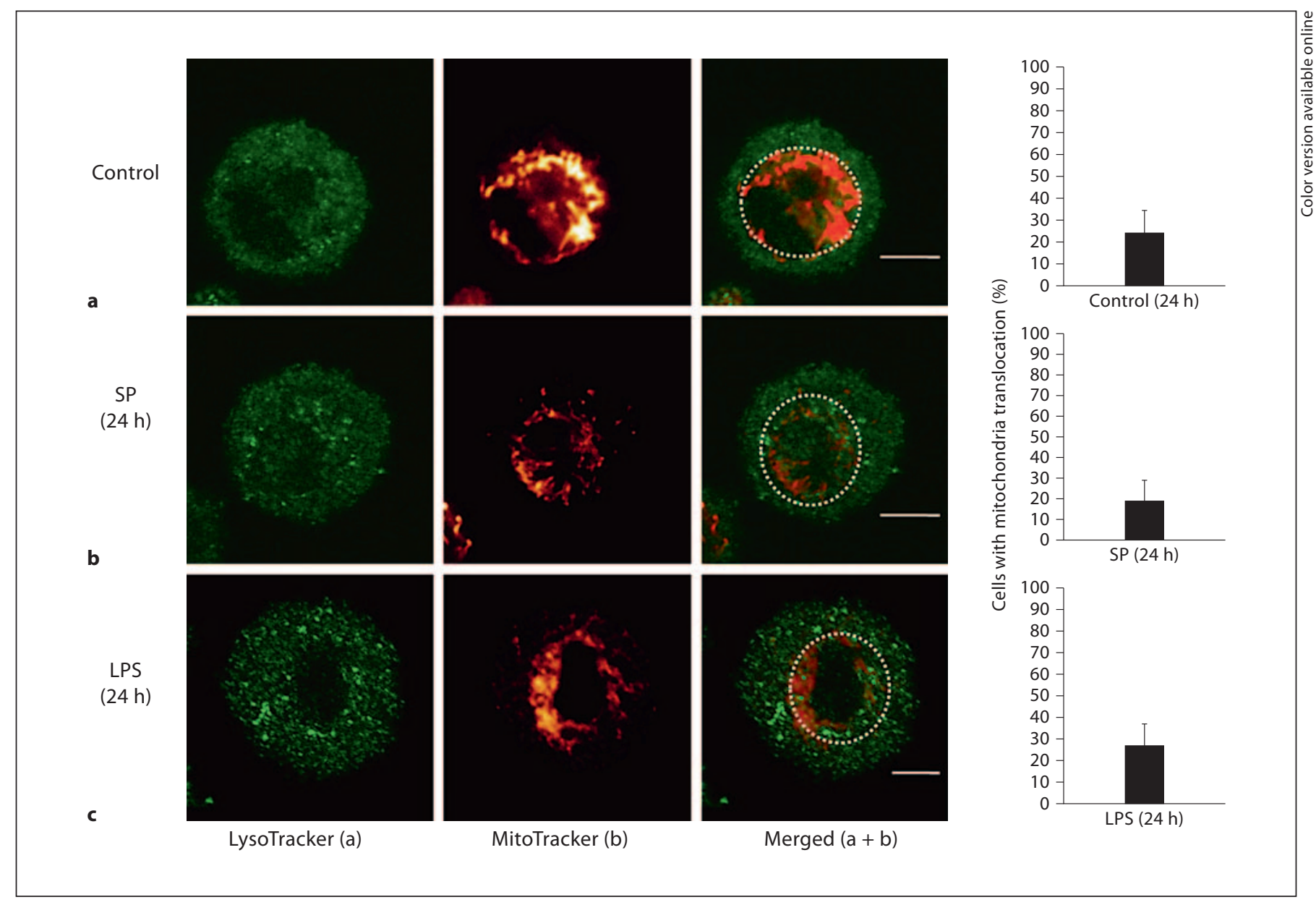

Fig. 5. Degranulation-associated mitochondrial translocation is reversible. LAD2 cells were stained with MitoTracker deep red probe $(20 \mathrm{nM})$ for $20 \mathrm{~min}$ and LysoTracker DND green probe (50 $\mathrm{nM}$ ) for $30 \mathrm{~min}$. The left panels depict granules in green and the middle panels represent mitochondrial fluorescence. The right panels represent images merged from the two previous panels. The white dashed circles outline the 'mitochondrial pool'. The graphs at the far right represent percentages of mast cells with mitochondrial translocation from 100 randomly selected cells. a Control groups. b SP (10 $\mu \mathrm{M}, 24 \mathrm{~h})$. c LPS (10 ng/ml, 24 h). Each experiment was repeated three times and was calculated by three independent operators. Scale bars $=5 \mu \mathrm{m}$. The colors refer to the online version of the figure. and streptavidin (125 ng/ml) show rapid (30 min) degranulation (fig. $6 \mathrm{c}$ ) at up to $35 \% \beta$-hex release (fig. $6 \mathrm{~d}$ ) and mitochondrial translocation (fig. 6c, lower panels).

\section{Discussion}

The present findings show that TNF secretion from human mast cells can occur through distinct pathways with different energy and calcium requirements, as well as mitochondrial dynamics. Degranulation is known to require calcium [23] and energy [33]. Here, we show that this process requires much more energy and calcium than de novo synthesized TNF release. The preformed nature of rapid released TNF was confirmed by the treatment of transcriptional inhibitor actinomycin D which has little effect on blocking rapid TNF release. We used a high SP concentration $(10 \mu \mathrm{M})$ in order to induce maximum degranulation. Such a high concentration has also been used previously to induce maximal LAD2 cell activation [6]. Moreover, only SP concentrations $>1 \mu \mathrm{M}$ were reported to be able to enhance the rate of oxygen consumption of isolated cardiac cell mitochondria [34]. Other authors have reported secretion of preformed TNF 
Fig. 6. IgE/streptavidin-triggered hCBMC degranualtion and TNF secretion is associated with mitochondrial translocation. Mitochondrial translocation and degranulation in hCBMCs observed by confocal microscopy. The white dashed circles on the right panels outline the 'mitochondrial pool'. Mitochondrial distribution in resting (a), IgE-incubated (1 $\mu \mathrm{g} / \mathrm{ml})$ (b) and $\operatorname{IgE}(1 \mu \mathrm{g} / \mathrm{ml})+$ streptavidin $(125 \mathrm{ng} / \mathrm{ml})$ stimulated (c) cells for $30 \mathrm{~min}$. Cells were stained with LysoTracker (a, green) and MitoTracker (b, red). Scale bars $=5 \mu \mathrm{m}$. The colors refer to the online version of the figure. $\mathbf{d} \beta$-hex release was measured $(\mathrm{n}=$ 3). ${ }^{*} \mathrm{p}<0.05$.

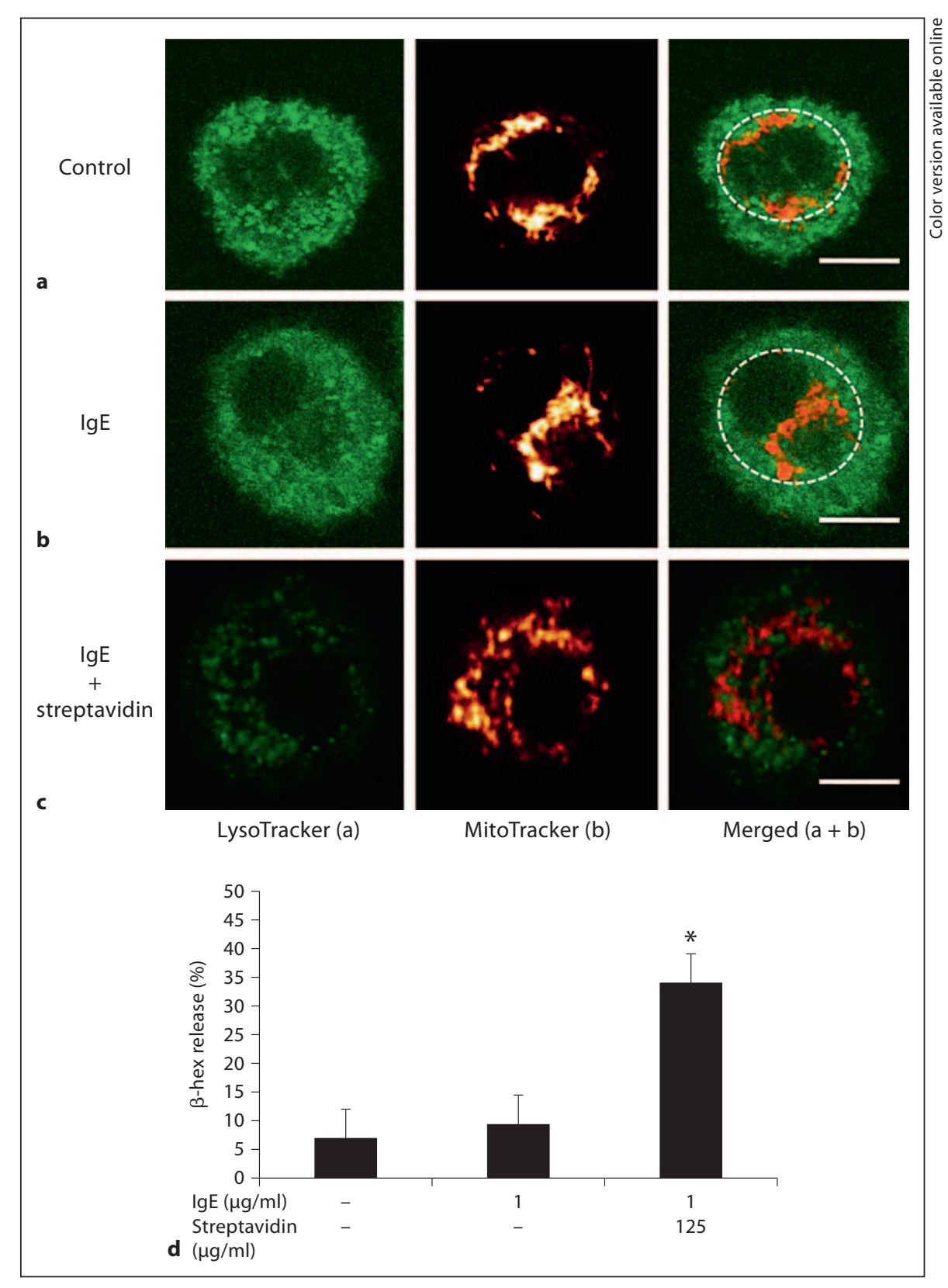

from mast cells in different species by different triggers $[4,35,36]$. However, there was no attempt to investigate how this secretion differs from de novo synthesis and release. Delayed ( $24 \mathrm{~h}$ ) TNF release could not be from continuous degranulation because morphological observations of SP-stimulated mast cells showed no degranulation at $24 \mathrm{~h}$. It would have been desirable, instead of SP, to use peptidoglycan, which has been reported to induce degranulation from rodent mast cells [37]. However, LAD2 cells are unresponsive to peptidoglycan [38].
We especially show that mast cell-preformed TNF secretion is associated with mitochondrial translocation to the cell surface. Mitochondrial translocation was confirmed using hCBMCs stimulated by IgE/streptavidin. These results indicate that such mitochondrial translocation is not due to any specific trigger or the leukemic nature of LAD2 cells. We recently showed that mast cell degranulation is tightly associated with mitochondrial morphological changes [39] and functions [40]. One possible explanation for our findings is that mitochondria 
translocate close to the secretory granules in order to provide energy locally, possibly for the granules to fuse with the plasma membrane and undergo exocytosis as shown for lymphocyte chemotaxis [26]. Mitochondrial translocation may also be needed to maintain optimal local calcium levels necessary for exocytosis [23], most likely for the calcium-dependent proteins involved in degranulation, such as the soluble $\mathrm{N}$-ethylmaleimide-sensitive factor attachment protein and the vesicle-associated membrane protein 8 [41]. It was previously shown that mitochondrial translocation was necessary to keep calcium channels open at the 'immunological synapse' in activated T cells [27].

Mitochondrial health is maintained through autophagy $[42,43]$. The normal appearance and distribution of mitochondria in mast cells $24 \mathrm{~h}$ after SP stimulation may be either because fragmented mitochondria underwent fusion and translocated back to the perinuclear region or because there was biogenesis of new mitochondria and digestion of old mitochondria through autophagy. The latter possibility is supported by a recent paper reporting that inhibition of autophagy blocks mast cell secretion [44]. Unlike degranulation, selective mast cell release of de novo synthesized mediators [11] could involve vesicular traffic that requires negligible and hard to measure calcium and energy levels. For instance, differential release of serotonin without degranulation involved small vesicles shuttling serotonin from secretory granules to the cell surface [45]. Similarly, IL-1 induced selective release of de novo synthesized IL- 6 contained within small vesicles [13]. Vesicular secretion may also be involved in the ability of corticotropin-releasing hormone to induce selective release of vascular endothelial growth factor without degranulation [46].

The regulatory processes investigated here may be applicable to the release of the mediators and could help explain how human mast cells participate in diverse biological processes. Mitochondrial dynamics may be necessary for a rapid mast cell response to an environmental trigger, as opposed to a delayed mediator release in other conditions, such as inflammation [47], innate and acquired immunity [1] or metabolic diseases [22]. An implied importance of our findings could be the possibility of inhibition of mast cell mitochondrial translocation targeted as antiallergic therapy, while permitting de novo synthesis of molecules, such as vascular endothelial growth factor which is useful in would healing. A better understanding of the mitochondrial dynamics involved in mast cell activation may permit individualized therapy for allergic and inflammatory disorders.

\section{Acknowledgments}

This work was supported in part by NIH grant R01 AR47652 and Safe Minds to T.C.T. We thank Swedish Orphan Biovitrum Sverige AB (Stockholm, Sweden) for their kind gift of recombinant human stem cell factor and Dr. A.S. Kirshenbaum (National Institutes of Health) for the supply of LAD2 mast cells. B. Zhang was supported by a graduate fellowship from Galenica, SA (Athens, Greece). K.-D. Alysandratos and A. Angelidou are recipients of postgraduate scholarships from the Hellenic State Scholarships Foundation (Athens, Greece). Current addresses of K.-D.A.: Department of Internal Medicine, University of Texas Southwestern Medical Center, Dallas, TX 75390, USA; and A.A.: Department of Pediatrics, University of Texas Southwestern, Children's Medical Center, Dallas, TX 75390, USA.

\section{References}

1 Galli SJ, Nakae S, Tsai M: Mast cells in the development of adaptive immune responses. Nat Immunol 2005;6:135-142.

2 Theoharides TC, Kalogeromitros D: The critical role of mast cell in allergy and inflammation. Ann NY Acad Sci 2006;1088: 78-99.

3 Gordon JR, Galli SJ: Mast cells as a source of both preformed and immunologically inducible TNF- $\alpha /$ cachectin. Nature 1990;346: 274-276.

-4 Olszewski MB, Groot AJ, Dastych J, Knol EF: TNF trafficking to human mast cell granules: mature chain-dependent endocytosis. J Immunol 2007;178:5701-5709.
5 Kirshenbaum AS, Akin C, Wu Y, Rottem M, Goff JP, Beaven MA, Rao VK, Metcalfe DD: Characterization of novel stem cell factor responsive human mast cell lines LAD 1 and 2 established from a patient with mast cell sarcoma/leukemia; activation following aggregation of FcepsilonRI or FcgammaRI. Leuk Res 2003;27:677-682.

6 Kulka M, Sheen CH, Tancowny BP, Grammer LC, Schleimer RP: Neuropeptides activate human mast cell degranulation and chemokine production. Immunology 2007;123: 398-410.

7 Varadaradjalou S, Feger F, Thieblemont N, Hamouda NB, Pleau JM, Dy M, Arock M: Toll-like receptor 2 (TLR2) and TLR4 differentially activate human mast cells. Eur J Immunol 2003;33:899-906.
-8 McCurdy JD, Olynych TJ, Maher LH, Marshall JS: Cutting edge: distinct Toll-like receptor 2 activators selectively induce different classes of mediator production from human mast cells. J Immunol 2003;170: 1625-1629.

\9 Kubo Y, Fukuishi N, Yoshioka M, Iriguchi S, Imajo S, Yasui Y, Matsui N, Akagi M: Bacterial components regulate the expression of Toll-like receptor 4 on human mast cells. Inflamm Res 2007;56:70-75.

10 Bandeira-Melo C, Sugiyama K, Woods LJ, Weller PF: Cutting edge: eotaxin elicits rapid vesicular transport-mediated release of preformed IL-4 from human eosinophils. J Immunol 2001;166:4813-4817. 
11 Theoharides TC, Kempuraj D, Tagen M, Conti P, Kalogeromitros D: Differential release of mast cell mediators and the pathogenesis of inflammation. Immunol Rev 2007;217:65-78.

$\checkmark 12$ Theoharides TC, Bondy PK, Tsakalos ND, Askenase PW: Differential release of serotonin and histamine from mast cells. Nature 1982;297:229-231.

13 Kandere-Grzybowska K, Letourneau R, Kempuraj D, Donelan J, Poplawski S, Boucher W, Athanassiou A, Theoharides TC: IL-1 induces vesicular secretion of IL- 6 without degranulation from human mast cells. J Immunol 2003;171:4830-4836.

-14 Tamir H, Theoharides TC, Gershon MD, Askenase PW: Serotonin storage pools in basophil leukemia and mast cells: characterization of two types of serotonin binding protein and radioautographic analysis of the intracellular distribution of $\left[{ }^{3} \mathrm{H}\right]$ serotonin. J Cell Biol 1982;93:638-647.

$\checkmark 15$ Theoharides TC, Alysandratos KD, Angelidou A, Delivanis DA, Sismanopoulos N, Zhang B, Asadi S, Vasiadi M, Weng Z, Miniati A, Kalogeromitros D: Mast cells and inflammation. Biochim Biophys Acta 2012; 1822:21-33.

16 Theoharides TC, Zhang B, Kempuraj D, Tagen M, Vasiadi M, Angelidou A, Alysandratos KD, Kalogeromitros D, Asadi S, Stavrianeas N, Peterson E, Leeman S, Conti P: IL-33 augments substance P-induced VEGF secretion from human mast cells and is increased in psoriatic skin. Proc Natl Acad Sci USA 2010;107:4448-4453.

-17 Sayed BA, Christy A, Quirion MR, Brown MA: The master switch: the role of mast cells in autoimmunity and tolerance. Annu Rev Immunol 2008;26:705-739.

18 Galli SJ, Grimbaldeston M, Tsai M: Immunomodulatory mast cells: negative, as well as positive, regulators of immunity. Nat Rev Immunol 2008;8:478-486.

19 Reinstein E, Mekori YA, Mor A: Autoimmunity and mast cell-related diseases. Expert Rev Clin Immunol 2008;4:267-274.

20 Weller K, Foitzik K, Paus R, Syska W, Maurer M: Mast cells are required for normal healing of skin wounds in mice. FASEB J 2006;20:2366-2368.

21 Theoharides TC, Conti P: Mast cells: the Jekyll and Hyde of tumor growth. Trends Immunol 2004;25:235-241.

-22 Theoharides TC, Sismanopoulos N, Delivanis DA, Zhang B, Hatziagelaki EE, Kalogeromitros D: Mast cells squeeze the heart and stretch the gird: their role in atherosclerosis and obesity. Trends Pharmacol Sci 2011; $32: 534-542$.
23 Douglas WW: Stimulus-secretion coupling: variations on the theme of calcium-activated exocytosis involving cellular and extracellular sources of calcium. Ciba Found Symp 1978;54:61-90.

24 Chan DC: Mitochondria: dynamic organelles in disease, aging, and development. Cell 2006;125:1241-1252.

25 Campello S, Scorrano L: Mitochondrial shape changes: orchestrating cell pathophysiology. EMBO Rep 2010;11:678-684.

26 Campello S, Lacalle RA, Bettella M, Manes S, Scorrano L, Viola A: Orchestration of lymphocyte chemotaxis by mitochondrial dynamics. J Exp Med 2006;203:2879-2886.

27 Quintana A, Schwindling C, Wenning AS, Becherer U, Rettig J, Schwarz EC, Hoth M: T cell activation requires mitochondrial translocation to the immunological synapse. Proc Natl Acad Sci USA 2007;104:14418-14423.

28 Liu X, Hajnoczky G: Ca2+-dependent regulation of mitochondrial dynamics by the Miro-Milton complex. Int J Biochem Cell Biol 2009;41:1972-1976.

29 Kempuraj D, Papadopoulou NG, Lytinas M, Huang M, Kandere-Grzybowska K, Madhappan B, Boucher W, Christodoulou S, Athanassiou A, Theoharides TC: Corticotropin-releasing hormone and its structurally related urocortin are synthesized and secreted by human mast cells. Endocrinology $2004 ; 145: 43-48$.

30 Sundstrom JB, Hair GA, Ansari AA, Secor WE, Gilfillan AM, Metcalfe DD, Kirshenbaum AS: IgE-FcepsilonRI interactions determine HIV coreceptor usage and susceptibility to infection during ontogeny of mast cells. J Immunol 2009;182:6401-6409.

-31 Johnson RG, Carty SE, Fingerhood BJ, Scarpa A: The internal $\mathrm{pH}$ of mast cell granules. FEBS Lett 1980;120:75-79.

32 Wu M, Baumgart T, Hammond S, Holowka D, Baird B: Differential targeting of secretory lysosomes and recycling endosomes in mast cells revealed by patterned antigen arrays. J Cell Sci 2007;120:3147-3154.

33 Johanson T: Energy metabolism in rat mast cells in relation to histamine secretion. Pharmacol Toxicol 1987;61:1-20.

- 34 Prabhakar NR, Runold M, Kumar GK, Cherniack NS, Scarpa A: Substance P and mitochondrial oxygen consumption: evidence for a direct intracellular role for the peptide. Peptides 1989;10:1003-1006.

35 Oskeritzian CA, Alvarez SE, Hait NC, Price MM, Milstien S, Spiegel S: Distinct roles of sphingosine kinases 1 and 2 in human mastcell functions. Blood 2008;111:4193-4200.

36 Mor A, Ben-Moshe O, Mekori YA, Kloog Y: Inhibitory effect of farnesylthiosalicylic acid on mediators release by mast cells: preferential inhibition of prostaglandin $\mathrm{D}(2)$ and tumor necrosis factor-alpha release. Inflammation 2010;34:314-318.
37 Supajatura V, Ushio H, Nakao A, Akira S, Okumura K, Ra C, Ogawa H: Differential responses of mast cell Toll-like receptors 2 and 4 in allergy and innate immunity. J Clin Invest 2002;109:1351-1359.

- 38 Yoshioka M, Fukuishi N, Iriguchi S, Ohsaki $\mathrm{K}$, Yamanobe H, Inukai A, Kurihara D, Imajo N, Yasui Y, Matsui N, Tsujita T, Ishii A, Seya T, Takahama M, Akagi M: Lipoteichoic acid downregulates FcepsilonRI expression on human mast cells through Toll-like receptor 2. J Allergy Clin Immunol 2007;120: 452-461.

- 39 Zhang B, Alysandratos KD, Angelidou A, Asadi S, Sismanopoulos N, Delivanis DA, Weng Z, Miniati A, Vasiadi M, KatsarouKatsari A, Miao B, Leeman SE, Kalogeromitros D, Theoharides TC: Human mast cell degranulation and preformed TNF secretion require mitochondrial translocation to exocytosis sites: relevance to atopic dermatitis. J Allergy Clin Immunol 2011;127:1522-1531.

40 Zhang B, Alysandratos KD, Angelidou A, Kempuraj D, Tagen M, Vasiadi M, Asadi S, Theoharides TC: TNF secretion from human mast cells is regulated by mitochondrial dynamics and mitochondrial uncoupling protein 2 (UCP2). J Immunol 2010;184:11.

41 Puri N, Roche PA: Mast cells possess distinct secretory granule subsets whose exocytosis is regulated by different SNARE isoforms. Proc Natl Acad Sci USA 2008; 105:25802585.

42 Hyde BB, Twig G, Shirihai OS: Organellar vs cellular control of mitochondrial dynamics. Semin Cell Dev Biol 2010;21:575-581.

43 Klionsky DJ, Emr SD: Autophagy as a regulated pathway of cellular degradation. Science 2000;290:1717-1721.

-44 Ushio H, Ueno T, Kojima Y, Komatsu M, Tanaka S, Yamamoto A, Ichimura Y, Ezaki J, Nishida K, Komazawa-Sakon S, Niyonsaba F, Ishii T, Yanagawa T, Kominami E, Ogawa H, Okumura K, Nakano H: Crucial role for autophagy in degranulation of mast cells. J Allergy Clin Immunol 2011;127:1267-1276. e6.

45 Kops SK, Theoharides TC, Cronin CT, Kashgarian MG, Askenase PW: Ultrastructural characteristics of rat peritoneal mast cells undergoing differential release of serotonin without histamine and without degranulation. Cell Tissue Res 1990;262:415-424.

-46 Cao J, Papadopoulou N, Kempuraj D, Boucher WS, Sugimoto K, Cetrulo CL, Theoharides TC: Human mast cells express corticotropin-releasing hormone $(\mathrm{CRH})$ receptors and CRH leads to selective secretion of vascular endothelial growth factor. J Immunol 2005; 174:7665-7675.

-47 Theoharides TC: Mast cells and pancreatic cancer. N Engl J Med 2008;358:1860-1861. 